\title{
Characterization of two diesel fuel degrading microbial consortia enriched from a non acclimated, complex source of microorganisms
}

\author{
Giulio Zanaroli', Sara Di Toro ${ }^{1,2}$, Daniela Todaro², Giovanna C Varese 3 , Antonio Bertolotto², Fabio Fava ${ }^{\text {* }}$
}

\begin{abstract}
Background: The bioremediation of soils impacted by diesel fuels is very often limited by the lack of indigenous microflora with the required broad substrate specificity. In such cases, the soil inoculation with cultures with the desired catabolic capabilities (bioaugmentation) is an essential option. The use of consortia of microorganisms obtained from rich sources of microbes (e.g., sludges, composts, manure) via enrichment (i.e., serial growth transfers) on the polluting hydrocarbons would provide bioremediation enhancements more robust and reproducible than those achieved with specialized pure cultures or tailored combinations (co-cultures) of them, together with none or minor risks of soil loading with unrelated or pathogenic allocthonous microorganisms.

Results: In this work, two microbial consortia, i.e., ENZ-G1 and ENZ-G2, were enriched from ENZYVEBA (a complex commercial source of microorganisms) on Diesel (G1) and HiQ Diesel (G2), respectively, and characterized in terms of microbial composition and hydrocarbon biodegradation capability and specificity.

ENZ-G1 and ENZ-G2 exhibited a comparable and remarkable biodegradation capability and specificity towards nC10 to $\mathrm{n}$-C24 linear paraffins by removing about $90 \%$ of $1 \mathrm{~g} \mathrm{I}^{-1}$ of diesel fuel applied after 10 days of aerobic shaken flask batch culture incubation at $30^{\circ} \mathrm{C}$. Cultivation dependent and independent approaches evidenced that both consortia consist of bacteria belonging to the genera Chryseobacterium, Acinetobacter, Psudomonas, Stenotrophomonas, Alcaligenes and Gordonia along with the fungus Trametes gibbosa. However, only the fungus was found to grow and remarkably biodegrade G1 and G2 hydrocarbons under the same conditions. The biodegradation activity and specificity and the microbial composition of ENZ-G1 and ENZ-G2 did not significantly change after cryopreservation and storage at $-20^{\circ} \mathrm{C}$ for several months.

Conclusions: ENZ-G1 and ENZ-G2 are very similar highly enriched consortia of bacteria and a fungus capable of extensively degrading a broad range of the hydrocarbons mainly composing diesel fuels. Given their remarkable biodegradation potential, stability and resistance to cryopreservation, both consortia appear very interesting candidates for bioaugmentation operations on Diesel fuel impacted soils and sites.
\end{abstract}

\section{Background}

Diesel fuels are complex mixtures of saturated hydrocarbons (primarily paraffins including $n$, iso, and cycloparaffins), and aromatic hydrocarbons (including naphthalenes and alkylbenzenes) obtained from the middle-distillate, gas-oil fraction during petroleum separation. Due to their massive production and use as fuels for transportation, they are among the most common sources of organic pollutants for the surface soil. They

\footnotetext{
* Correspondence: fabio.fava@unibo.it

'DICASM, Faculty of Engineering, University of Bologna, via Terracini 28, 40131 Bologna, Italy
}

also impact the subsurface soil through leaking from underground storage tanks and pipelines. Due to their mobility in soil, such released diesel fuel hydrocarbons can reach water intakes and/or groundwater reservoirs, thus generating relevant risks for humans and other living organisms [1].

The majority of petroleum-derived hydrocarbons can be biodegraded by several microbial strains each however capable of breaking down a specific group of molecules; the biodegradation potential generally decreases by moving from n-alkanes to branched alkanes, lowmolecular weight $\mathrm{n}$-alkyl aromatics, monoaromatics,
C Biomed Central

C 2010 Zanaroli et al; licensee BioMed Central Ltd. This is an Open Access article distributed under the terms of the Creative Commons Attribution License (http://creativecommons.org/licenses/by/2.0), which permits unrestricted use, distribution, and reproduction in any medium, provided the original work is properly cited. 
cyclic alkanes and polynuclear aromatics [2-4]. However, the mineralization of complex hydrocarbon mixtures such as those composing diesel fuels, usually requires the co-existence and effective cooperation of several specialized microorganisms with complementary substrate specificity [5-7]. Microbial consortia with such physiological and metabolic features might not exist in a soil, in particular if only recently impacted by a diesel fuel release, and this is often the main cause of the poor bio-treatability of diesel fuel contaminated soils and sites. In such cases, the inoculation of the impacted soil with high concentrations of characterized cultures of highly specialized microbes (bioaugmentation) is one of the most promising options for getting its sustainable remediation.

The use of pure cultures and co-cultures of hydrocarbon-degrading microorganisms has been tested with interesting results on hydrocarbons contaminated soils; however, the behaviour and metabolic activity of the applied cultures are very often not those expected and they are often not reproducible [8-11]. Recently, the use of complex microbial sources, such as those occurring in sludge, manure or compost, has been proposed. They generally carry a high diversity of bacteria and fungi with a high genetic and metabolic diversity, along with a variety of essential nutrients that might remarkably contribute to sustain the survival and colonization of allocthonous microbes in the inoculated biotope [12-19]. However, some of such complex microbial sources contain remarkable loads of non-necessary biotope extraneous microbes, along with pathogenic bacteria, such as Salmonella spp., Listeria monocytogenes, Campylobacter coli and C. jejuni [20,21], and therefore their application in bioaugmentation strategies might provide environmental risks that should be carefully evaluated. On the contrary, the use of the specialized portion of microflora of such sources would provide higher and more reproducible pollutant mineralization rates and extents with respect to those achievable with pure or tailored mixed cultures of specialized microorganisms $[7,9,22]$. This is mostly due to the ability of the members of enriched consortia to retain their native ability to cooperate with each other, also with strains apparently without biodegradation capabilities, that might contribute to the growth and activity of those in charge for the final pollutant mineralization [6]. However, the stability of such complex microbial populations in terms of microbial composition and growth and biodegradation behaviour in the contaminated matrices needs to be determined and assessed, also after prolonged maintenance under both growing and storage conditions [7,23,24].

ENZYVEBA, a partially characterized complex consortium of not-adapted microorganisms developed through prolonged stabilization of cow manure [25-28], was recently applied in bioaugmentation studies $[15,16]$ and found capable of intensifying the aerobic remediation of a soil freshly contaminated by two different diesel fuels, i.e. regular diesel fuel (G1) and HiQ diesel fuel (G2), by acting as a source of both exogenous specialized microorganisms and nutrients [16]. Thus, it was of interest to obtain and characterize its native microbial population capable of diesel fuel hydrocarbon degradation. Two highly enriched microbial populations were obtained from ENZYVEBA through 5 sequential transfers in mineral minimal medium with G1 or G2 as growth substrates. They were then characterized in terms of biodegradation extents, rates and specificity, microbial composition and stability upon cryopreservation, in order to determine their actual potential to be applied in bioaugmentation procedures for diesel fuel contaminated sites. This study is one of the few in which two highly performing diesel fuel mineralizing consortia are obtained from composted related matrices and are described; further it is the first one in which the presence and the key role of a fungus in consortia obtained through conventional enrichment procedures for bacteria is documented and characterized.

\section{Results}

Diesel fuel-degrading consortia obtained from ENZYVEBA

The two microbial consortia ENZ-G1 and ENZ-G2 were obtained from ENZYVEBA through 5 consecutive culture transfers $(2 \% \mathrm{v} / \mathrm{v})$ on minimum mineral medium (MMM) for bacteria amended with Diesel (G1) and HiQ Diesel (G2) respectively applied at $1 \mathrm{~g} \mathrm{l}^{-1}$ as the main carbon and energy source. Once inoculated in duplicated sterile cultures of MMM with their own diesel fuel at $1 \mathrm{~g} \mathrm{l}^{-1}$ in the presence of $20 \mathrm{mg} \mathrm{l}^{-1}$ of yeast extract and incubated at $30^{\circ} \mathrm{C}$ under shaken flask conditions, both ENZ-G1 and ENZ-G2 degraded rapidly and extensively G1 and G2 hydrocarbons, respectively, with rates which were in average, during the first four days of incubation, $160.9 \pm 7.9$ and $175.7 \pm 3.1 \mathrm{mg}$ of overall hydrocarbons depleted $\mathrm{l}^{-1}$ day $^{-1}$, respectively. The hydrocarbon degradation then proceeded slowly up to the tenth day of incubation, when the initial amount of overall applied hydrocarbons resulted to be removed by $90.8 \pm 1.2 \%$ and $89.4 \pm 0.1 \%$ in ENZ-G1 and ENZ-G2, respectively (Figure $1 \mathrm{~A}$ ). The activity of both consortia was mainly directed towards linear C10-C24 paraffins; among these, medium-high MW n-alkanes (C18-C24) were in general degraded more extensively than medium-low MW n-alkanes during the first days of incubation (Figure 2, Table 1). In particular, depletions around $70 \%$ and $60 \%$ were detected for $\mathrm{C} 18-\mathrm{C} 24$ and $\mathrm{C} 12-\mathrm{C} 16$ $\mathrm{n}$-paraffins, respectively, after 1 day of incubation in ENZ-G1 culture and after 2 days of incubation in ENZG2 culture, whereas degradation of $21 \%-22 \%$ was 
observed for n-decane after two days of incubation (Table 1). However, comparable final depletions of 94\%$100 \%$ were achieved for all $n$-paraffines in both cultures at the end of incubation (10 days) (Figure 2, Table 1). No GC-FID detectable intermediates were observed to accumulate in the ENZ-G1 and ENZ-G2 cultures throughout the 10 days of incubation. The bacterial biomass able to grow on TSA medium grew rapidly during the first 3 days of incubation by increasing from $5.4 \times$ $10^{6} \pm 7.5 \times 10^{4}$ and $6.9 \times 10^{6} \pm 6.0 \times 10^{5} \mathrm{CFU} \mathrm{ml}{ }^{-1}$ observed at the beginning of incubation in ENZ-G1 and ENZ-G2 cultures, respectively, to values of $1.0 \times 10^{9} \pm$ $1.5 \times 10^{7}$ and $1.3 \times 10^{9} \pm 1.8 \times 10^{8} \mathrm{CFU} \mathrm{m}{ }^{-1}$, respectively (Figure 1B).

After cryopreservation and storage at $-20^{\circ} \mathrm{C}$ for 6 months, ENZ-G1 and ENZ-G2 displayed G1 and G2 hydrocarbon biodegradation rates, extents and specificity as well as cultivable bacterial biomass growth profiles comparable to those observed for the same consortia under the same culture conditions before storage (Figure 1). In particular, average degradation rates of 143.9 \pm 6.4 and $162.7 \pm 2.2 \mathrm{mg}$ of overall hydrocarbons depleted $\mathrm{l}^{-1}$ day $^{-1}$ were detected after four days of incubation in ENZ-G1 and ENZ-G2 cultures, respectively, and final depletions of overall applied hydrocarbons of $90.7 \pm 0.6 \%$ (ENZ-G1) and $88.2 \pm 0.4 \%$ (ENZ-G2) were observed at the end of incubation (Figure 1A). In addition, the concentration of the bacterial biomass able to grow on TSA medium increased from $7.6 \times 10^{6} \pm 1.8 \times$ $10^{6}$ to $5.2 \times 10^{8} \pm 4.4 \times 10^{7} \mathrm{CFU} \mathrm{ml}^{-1}$ and from $1.2 \times$ $10^{7} \pm 3.2 \times 10^{5}$ to $5.7 \times 10^{8} \pm 3.6 \times 10^{7} \mathrm{CFU} \mathrm{ml}{ }^{-1}$ during the first 3 days of incubation in ENZ-G1 and ENZG2 cultures, respectively (Figure 1B). A careful observation of the morphology of colonies grown on TSA plates after 5 days of incubation indicated that both consortia were composed by seven bacterial components, two of which were numerically predominant on the others.

\section{Characterization of ENZ-G1 and ENZ-G2}

The bacterial composition of ENZ-G1 and ENZ-G2 was characterized after the $5^{\text {th }}$ enrichment cycle by using two cultivation-independent methods based on $16 \mathrm{~S}$ rRNA genes screening, i.e. $16 \mathrm{~S}$ rDNA clonal libraries and PCR-DGGE fingerprinting of community $16 \mathrm{~S}$ rDNA. Only three different OTUs were detected in each clonal library. Both clonal libraries from ENZ-G1 and ENZ-G2 cultures were dominated by OTU1, that represented $96 \%$ of screened clones and was $99 \%$ identical to 16S rRNA gene sequence of Acinetobacter baumannii strain NBRAJG89. OTU2 and OTU3 showed their highest sequence similarity to a Paracoccus versutus strain and represented 2\% each of ENZ-G1 clones. On the contrary, 4\% of ENZ-G2 clones were equally represented by OTU4, having 95\% sequence identity with an uncultured Gammaproteobacterium, and by OTU5, having 99\% sequence similarity with an uncultured Achromobacter sp. clone (Table 2 ).

On the other hand, according to DGGE analysis 7 main phylotypes apparently occurred in ENZ-G1 and ENZ-G2 cultures (Figure 3, lanes 1 and 3). ENZ-G1 consisted of phylotypes 1, 2, 3, 5 and 6, whereas ENZG2 comprised all the 7 phylotypes. Band excision and sequencing revealed that phylotype 1 belonged to Chryseobacterium genus of Bacteroidetes, phylotypes 2, 3 and 6 to the genera Acinetobacter, Pseudomonas and Stenotrophomonas of Gammaproteobacteria, respectively, phylotype 4 to the Sphingopyxis genus of Alphaproteobacteria and phylotype 5 to the genus Achromobacter of Betaproteobacteria (Table 2). Repeated attempts to PCR-amplify and sequence the DGGE band corresponding to phylotype 7 were unsuccessful.

DGGE analysis repeated on ENZ-G1 and ENZ-G2 after cryotreatment and storage at $-20^{\circ} \mathrm{C}$ evidenced the persistence of almost all the major components of the consortium (Figure 3). Only phylotypes 1 and 3 became undetectable in DGGE profiles of ENZ-G2 after storage and three sub-culturing steps (Figure 3, lane 4). On the other hand, phylotypes 2, 5 and 6 exhibited the highest relative band intensity in all profiles of both ENZ-G1 and ENZ-G2, thus suggesting they were the dominant members of both communities. Remarkably, the

Table 1 Degradation percentages of linear alkanes by ENZ-G1 and ENZ-G2 cultures

\begin{tabular}{|c|c|c|c|c|c|c|}
\hline \multirow[b]{2}{*}{ n-alkane } & \multicolumn{3}{|c|}{ Degradation percentage - ENZ-G1 } & \multicolumn{3}{|c|}{ Degradation percentage - ENZ-G2 } \\
\hline & 1 day & 2 days & 10 days & 1 day & 2 days & 10 days \\
\hline$n-C_{10}$ & $31,2 \pm 6,7$ & $22,6 \pm 1,6$ & $96,1 \pm 2,9$ & $14,1 \pm 4,0$ & $21,0 \pm 4,3$ & $100,0 \pm 0,0$ \\
\hline$n-C_{12}$ & $60,0 \pm 2,3$ & $84,4 \pm 3,1$ & $98,0 \pm 0,0$ & $24,7 \pm 2,3$ & $54,0 \pm 2,2$ & $100,0 \pm 0,0$ \\
\hline$n-C_{14}$ & $59,0 \pm 2,5$ & $82,3 \pm 2,8$ & $96,6 \pm 0,0$ & $27,3 \pm 3,9$ & $59,7 \pm 2,3$ & $100,0 \pm 0,0$ \\
\hline$n-C_{16}$ & $60,7 \pm 0,0$ & $79,4 \pm 0,0$ & $93,6 \pm 2,0$ & $29,5 \pm 9,8$ & $65,2 \pm 1,8$ & $100,0 \pm 0,0$ \\
\hline$n-C_{18}$ & $67,0 \pm 2,0$ & $86,4 \pm 2,9$ & $99,2 \pm 0,2$ & $34,0 \pm 3,3$ & $68,5 \pm 0,9$ & $100,0 \pm 0,0$ \\
\hline$n-C_{20}$ & $67,9 \pm 1,9$ & $82,9 \pm 1,8$ & $93,7 \pm 0,3$ & $40,6 \pm 2,0$ & $72,9 \pm 0,2$ & $100,0 \pm 0,0$ \\
\hline$n-C_{22}$ & $70,4 \pm 1,8$ & $85,6 \pm 1,2$ & $97,9 \pm 2,1$ & $38,8 \pm 1,7$ & $75,2 \pm 0,9$ & $100,0 \pm 0,0$ \\
\hline$n-C_{24}$ & $71,8 \pm 0,7$ & $87,1 \pm 2,2$ & $100,0 \pm 0,0$ & $42,7 \pm 2,9$ & $77,5 \pm 0,3$ & $100,0 \pm 0,0$ \\
\hline
\end{tabular}




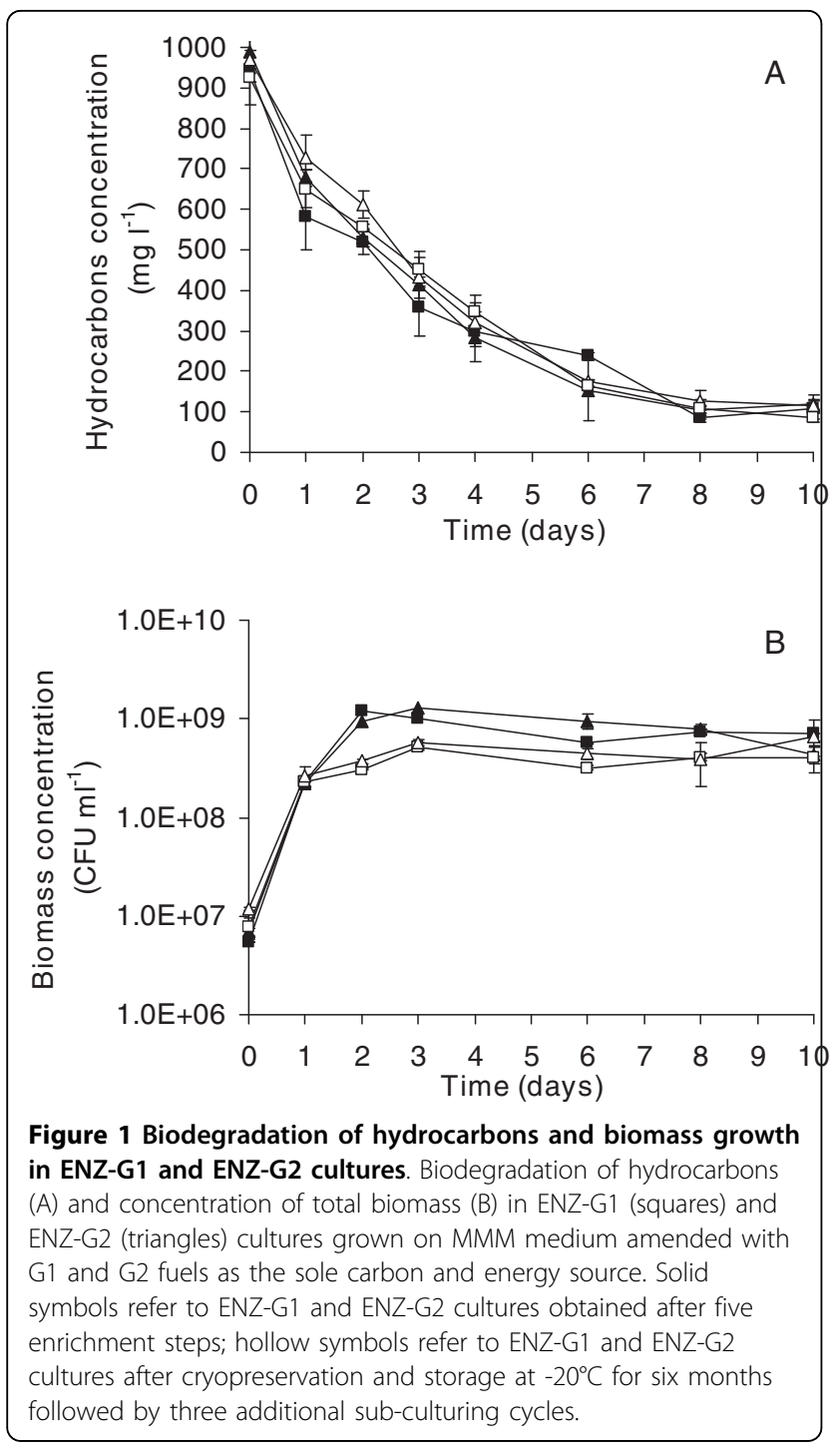

Acinetobacter genus represented by DGGE phylotype 2 was also the most abundant according to clone library screening (OTU1).

\section{Isolation of cultivable members of ENZ-G1 and ENZ-G2 consortia}

ENZ-G1 and ENZ-G2 plated on TSA displayed 6 and 7 different types of bacterial colonies, respectively. Over forty isolates were obtained from plates of ENZ-G1 or ENZ-G2. Those having the same colony morphology generated the same ARDRA profile. Thus 16S rRNA gene of one isolate for each unique restriction profile was sequenced for phylogenetic identification. Six pure cultures of bacteria, namely ENZ1 to ENZ6, were thus obtained from both ENZ-G1 and ENZ-G2 plated on TSA medium, and a seventh isolate (ENZ7) was obtained only from ENZ-G2; each isolate was transferred at least twice in liquid MMM with G1 or G2 at $1 \mathrm{~g} \mathrm{l}^{-1}$. One isolate, i.e. ENZ5, obtained from either ENZ-G1 and ENZ-G2, failed to grow at the second transfer. All the others bacterial isolates grew very poorly and slowly. Isolates ENZ1, ENZ4 and ENZ6 were placed in the genera Acinetobacter, Pseudomonas and Stenotrophomonas of Gammaproteobacteria, isolate ENZ3 in the genus Achromobacter of Betaproteobacteria, isolate ENZ2 into the genus Chryseobacterium of Bacteroidetes and isolate ENZ7 in the genus Gordonia of Actinobacteria (Table 3). Remarkably, 16S RNA gene sequence of isolate ENZ1 (Acinetobacter baumannii) was highly similar to that of DGGE phylotype 2 and to OTU 1 identified in clonal libraries; whereas isolate ENZ2 (Chryseobacterium taichungense) was highly similar to DGGE phylotype 1, isolate ENZ3 (Alcaligenes sp.) to DGGE phylotype 5, isolate ENZ4 (Pseudomonas stutzeri) to DGGE band 3 and isolate ENZ6 (Stenotrophomonas acidiminiphila) to DGGE phylotype 6 (Figure 4). Conversely, 16S rRNA sequence of isolate ENZ7 did not correspond to any of the phylotypes detected by DGGE or in clonal libraries of ENZ-G1 and ENZ-G2.

None of the characterized isolates degraded efficiently and in a reproducible manner G1 or G2 hydrocarbons under the liquid culture conditions described above adopted for determining ENZ-G1 and ENZ-G2 biodegradation potential (data not shown). No fungal colonies were observed to grow on TSA plates inoculated with ENZ-G1 and ENZ-G2 after 10 days of incubation. However, the use of MEA plates evidenced that both consortia contained fungi which displayed the same colony morphology (hyaline sterile mycelium). Some fungal isolates were obtained from ENZ-G1 or ENZ-G2 inoculated MEA plates but all of them were $100 \%$ identical to ITS gene sequences of several Trametes gibbosa strains. One of the fungal isolates, designated as ENZ8, was assayed for its ability to degrade G1 and G2 under the shaken flask batch conditions adopted for determining ENZ-G1 and ENZ-G2 biodegradation potential. It was found to remove $60 \%$ and $66 \%$ of overall applied G1 and G2 hydrocarbons, respectively, in 20 days of incubation (Figure 5). No GC-FID detectable intermediates were observed to accumulate in the cultures throughout their incubation. The fungal biomass grew rapidly during the first 5 days of incubation on G1 and G2 hydrocarbons, by increasing from 0.01 to about $0.40 \mathrm{~g}$ of dry biomass per $20 \mathrm{ml}$ of culture medium (Figure 5). Extracellular ligninolytic enzyme activities were detected throughout the experiment, although generally at concentrations which were low and changed with the sampling time. A comparable laccase activity was detected in the culture medium throughout incubation on both G1 and G2, with a maximum activity of 14.0 and 12.5 $\mathrm{Ul}^{-1}$, respectively, at the $10^{\text {th }}$ day of incubation (Figure 


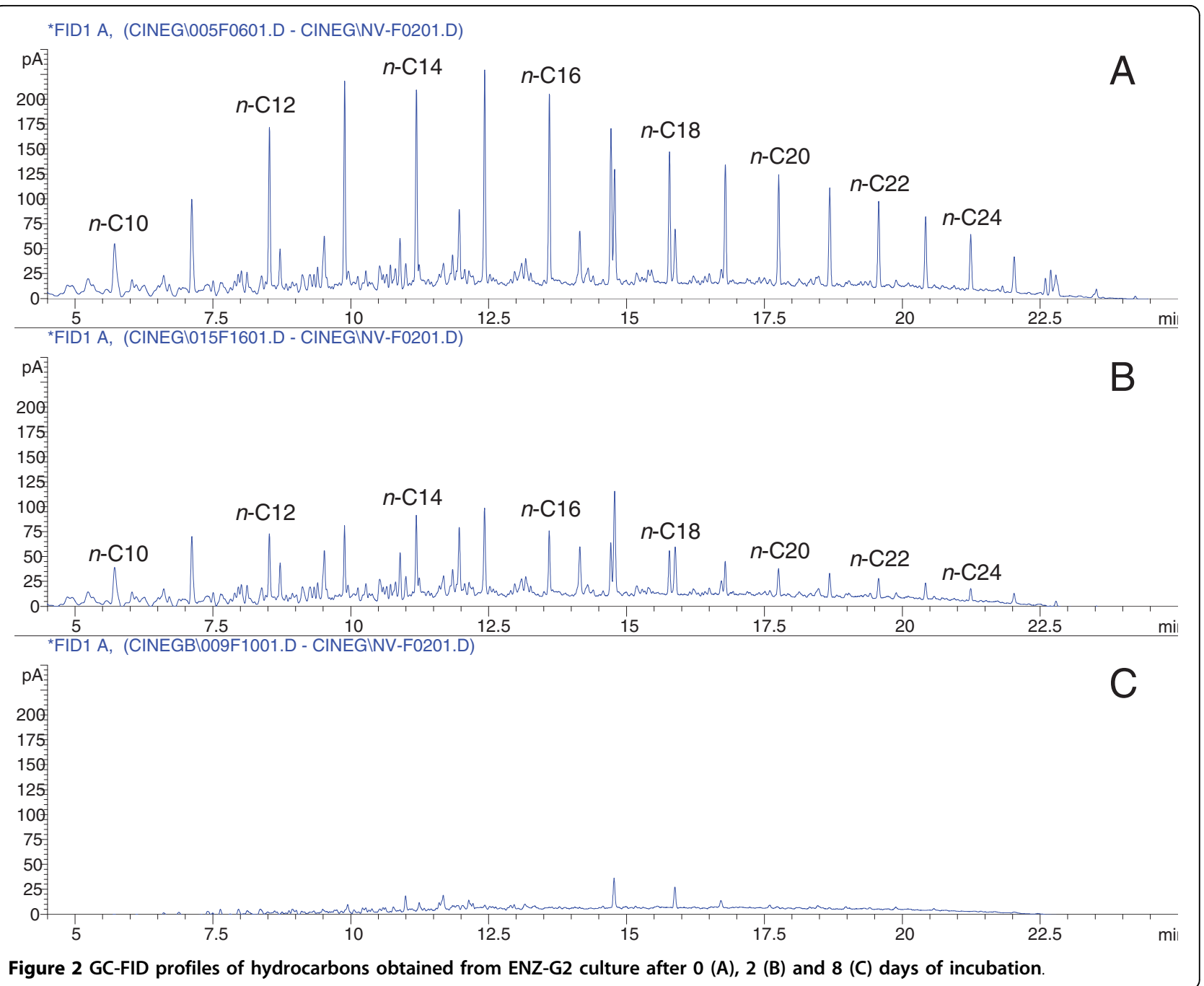

5). Mn- peroxidase activity was also detected when ENZ8 was grown on G2 hydrocarbons, in particular after 5 days on incubation (19.2 $\mathrm{Ul}^{-1}$, Figure 5B), whereas the same enzymatic activity remained below 2.5 $\mathrm{Ul}^{-1}$ during incubation with G1 (Figure 5A). Mn-independent peroxidase and lignino peroxidase activities were never detected.

\section{Discussion}

Despite the majority of hydrocarbon constituents of diesel fuels are biodegraded by several microorganisms commonly occurring in soil each capable of breaking down a specific group of molecules [1], the bioremediation of soils and sites contaminated by diesel fuels is often limited by the poor biodiversity of indigenous microflora and/or the scarcity of indigenous specialized microbes with the complementary substrate specificity required to degrade the different hydrocarbons occurring at the contaminated site $[7,29]$. ENZYVEBA, a complex source of bacteria and fungi obtained through the prolonged stabilization of high quality organic wastes, was recently found capable of enhancing the aerobic bioremediation of a pristine soil freshly contaminated by diesel fuels, by providing both exogenous specialized microorganisms and nutrients [16]. In the present work, two microbial consortia, i.e., ENZ-G1 and ENZ-G2, able to grow on G1 or G2 in the absence of other carbon and energy sources, were obtained from ENZYVEBA through a conventional enrichment procedure and deeply characterized. In the view of employing them in bioaugmentation strategies of diesel fuels impacted sites, their ability to retain their biodegradation potential and community composition after cryopreservation was also investigated.

Both ENZ-G1 and ENZ-G2 exhibited high diesel fuel hydrocarbons biodegradation rates and yields, being able to remove about $90 \%$ of the applied $1 \mathrm{~g} \mathrm{l}^{-1}$ of G1 and G2, respectively, in 10 days of shaken batch aerobic 
Table 2 Phylotypes detected in ENZ-G1 and ENZ-G2 consortia by clone library screening and DGGE analysis of 16S rRNA genes

\begin{tabular}{|c|c|c|c|c|c|}
\hline Consortium & Phylotype & $\begin{array}{l}\text { Phylogenetic } \\
\text { affiliation }\end{array}$ & $\begin{array}{l}\text { Closest relative } \\
\text { [GenBank Accession number] }\end{array}$ & Identity & $\begin{array}{l}\text { Corresponding } \\
\text { isolate }\end{array}$ \\
\hline $\begin{array}{l}\text { ENZ-G1 \& ENZ- } \\
\text { G2 }\end{array}$ & $\begin{array}{l}\text { DGGE band } \\
1\end{array}$ & Bacteroidetes & $\begin{array}{l}\text { Chryseobacterium taichungense type strain CC-TWGS1-8 } \\
\text { [AJ843132] }\end{array}$ & $98 \%$ & ENZ2 \\
\hline ENZ-G2 & $\begin{array}{l}\text { DGGE band } \\
4\end{array}$ & $\alpha$-proteobacteria & Sphingopyxis taejonensis Type strain JSS-54 [AF131297] & $99 \%$ & - \\
\hline ENZ-G1 & Clone OTU2 & & Paracoccus versutus strain Ten3 [AF437875] & $99 \%$ & - \\
\hline ENZ-G1 & Clone OTU3 & & Paracoccus versutus strain Ten3 [AF437875] & $89 \%$ & - \\
\hline $\begin{array}{l}\text { ENZ-G1 \& ENZ- } \\
\text { G2 }\end{array}$ & $\begin{array}{l}\text { DGGE band } \\
5\end{array}$ & $\beta$-proteobacteria & Alcaligenes sp. NyZ215 [EF540877] & $100 \%$ & ENZ3 \\
\hline $\begin{array}{l}\text { ENZ-G2 \& ENZ- } \\
\text { G2 }\end{array}$ & Clone OTU5 & & Uncultured Achromobacter sp. clone OUT11 [EU372808] & $99 \%$ & - \\
\hline $\begin{array}{l}\text { ENZ-G1 \& ENZ- } \\
\text { G2 }\end{array}$ & Clone OTU1 & $\gamma$-proteobacteria & Acinetobacter baumannii strain NBRAJG89 [EU661706] & $99 \%$ & ENZ1 \\
\hline $\begin{array}{l}\text { ENZ-G1 \& ENZ- } \\
\text { G2 }\end{array}$ & $\begin{array}{l}\text { DGGE band } \\
2\end{array}$ & & Acinetobacter baumannii strain NBRAJG89 [EU661706] & $99 \%$ & ENZ1 \\
\hline $\begin{array}{l}\text { ENZ-G1 \& ENZ- } \\
\text { G2 }\end{array}$ & $\begin{array}{l}\text { DGGE band } \\
3\end{array}$ & & Pseudomonas stutzeri strain SA1 [DQ059546] & $99 \%$ & ENZ4 \\
\hline $\begin{array}{l}\text { ENZ-G1 \& ENZ- } \\
\text { G2 }\end{array}$ & $\begin{array}{l}\text { DGGE band } \\
6\end{array}$ & & $\begin{array}{l}\text { Stenotrophomonas acidaminiphila strain NK } 2 . \mathrm{Ha}-5 \\
\text { [EU352763] }\end{array}$ & $95 \%$ & ENZ6 \\
\hline ENZ-G2 & Clone OTU4 & & Uncultured bacterium clone BANW729 [DQ264639] & $95 \%$ & - \\
\hline
\end{tabular}

culture incubation (Figure 1A). A comparable hydrocarbons biodegradation activity was displayed by both ENZ-G1 and ENZ-G2 after cryopreservation and storage at $-20^{\circ} \mathrm{C}$ for six months (Figure $1 \mathrm{~A}$ ). The two consortia also displayed a similar biodegradation specificity towards G1 and G2 hydrocarbons, which were biodegraded simultaneously and with rates and extents which were only slightly dependent on the hydrocarbon molecular weight (Figure 2, Table 1). No GC-FID detectable intermediates were observed in the culture medium and this suggests that the depleted hydrocarbons underwent mineralization. These findings are in substantial agreement with those already reported in the literature for aerobic bacteria growing on complex mixtures of aliphatic hydrocarbons [30-32]. Slightly higher biodegradation rates were observed in ENZ-G2 cultures, probably for the G2 content of chemical additives with detergent properties able to increase, as already hypothesized by Di Toro et al. [16], the bioavailability and, in turn, the biodegradation of G2 hydrocarbons. However, such a finding might also be ascribed to the slightly higher biodiversity of ENZ-G2 consortium with respect to ENZG1 (Figure 3). Indeed, ENZ-G1 and ENZ-G2 display a similar but not identical community structure. Both cultures include members of Bacteriodetes (Chryseobacterium taichungense), Gammaproteobacteria (Acinetobacter baumannii, Psudomonas stutzeri and Stenotrophomonas acidaminiphila), Betaproteobacteria (Alcaligenes sp.), Actinomycetes (Gordonia amicalis) and Alphaproteobacteria; however, the latter group is represented by Paracoccus versutus in ENZ-G1, and by Sphingopyxis taejonensis in ENZ-G2 (Tables 2 and 3). With the exception of the Alphaproteobacteria strains, all members of the two microbial consortia identified with cultivation-independent techniques could be isolated from the same consortia and cultivated on mineral medium with G1 or G2. On the contrary, Paracoccus and Sphingopyxis strains were never isolated in pure culture under the same conditions probably because of their poor cultivability [33] or/and low occurrence in ENZ-G1 and ENZ-G2 consortia. Differently, the Gordonia strain isolated from both consortia was not detected via $16 \mathrm{~S}$ rRNA gene clone library and DGGE analysis, probably because of the difficulties to brake up cells and obtain DNA from Actinomycetes with the DNA extraction protocol employed in this study relying on freeze and thaw cell lysis [34]. Several strains of ENZ-G1 and ENZ-G2 belong to bacterial species already reported in the literature for their ability to degrade aliphatic hydrocarbons. Indeed, several Acinetobacter, Pseudomonas, Stenotrophomonas, Alcaligenes, and Gordonia strains have been reported to grow on and/or degrade aliphatic and/or aromatic hydrocarbons or to enrich in diesel- and oilysludge-contaminated soils [6,9,12,35-40]. However, ENZ-G1 and ENZ-G2 bacterial biodiversity is higher than that displayed by any other hydrocarbon-degrading mixed culture reported so far in literature. Further, to our knowledge, this is the first study in which Paracoccus and Sphingopyxis strains are reported as members of aliphatic hydrocarbon-biodegrading consortia. The composition of ENZ-G1 and ENZ-G2 did not change significantly after cryopreservation. However, importantly, 
none of the bacterial isolates were able to stably and remarkably grow on G1 or G2 hydrocarbons in liquid cultures of MMM supplemented with G1 or G2 at $1 \mathrm{~g} \mathrm{l}^{-}$ 1 . This was quite surprising and can be ascribed to the inability of isolates to singly face the toxicity of the complex hydrocarbons mixture occurring in diesel fuel [41].

Such an unexpected finding induced new investigations addressed to search for the occurrence of fungi in the two consortia and fungal strains belonging to the Trametes gibbosa species able to grow on G1 and G2 hydrocarbons in shaken cultures of MMM were obtained from both ENZ-G1 and ENZ-G2. This was a quite surprising evidence as the enrichment procedure adopted for obtaining the two consortia was specific for bacteria, in terms of medium composition, mixing and incubation conditions adopted, and one of the most commonly applied for the selection of prominent hydrocarbon degrading mixed cultures described in the literature during the last two decades [22,42-45]. Several fungi are known to have the capability of degrading persistent pollutants. The microbial degradation of hydrocarbons by ligninolytic fungi has been intensively studied during the past few years [46] because they produce extracellular enzymes with very low substrate specificity, making them suitable for degradation of different compounds. The genus Trametes is probably the most actively investigated in the phylum of Basidiomycota for ligninolytic enzyme formation and use in a wide range of analytical, industrial, and environmental applications [47]. Trametes spp. are well known degraders of different organopollutants and T. gibbosa in particular has already been reported for its ability to degrade different dyes [48].

The co-presence of bacteria and fungi appear essential for the functionality of the consortium, as demonstrated by our data and confirm what already stated by other authors that showed that the mineralization of hydrocarbons in nature may require the combined efforts of both fungi and bacteria [49].

Thus, ENZ-G1 and ENZ-G2 display an overall biodiversity higher than those of other diesel fuel mineralizing aerobic consortia already reported in the literature and are the first ones consisting of stable consortium of bacteria and the fungus Trametes gibbosa, and probably for this ENZ-G1 and ENZ-G2 are the consortia with the broadest specificity and highest biodegradation potential among the diesel fuel biodegrading cultures reported so far in the literature.

Figure 3 DGGE analysis of ENZ-G1 and ENZ-G2 consortia. 16S rDNA-DGGE profiles of diesel fuel degrading ENZ-G1 and ENZ-G2 consortia enriched from ENZYVEBA before (lanes 1 and 3) and after a six-month chryopreservation at $-20^{\circ} \mathrm{C}$ (lanes 2 and 4). Numbered black arrows on left side indicate phylotypes detected as described in the text. White arrows indicate excised bands.

\section{Conclusions}

ENZ-G1 and ENZ-G2 are two new aerobic microbial consortia capable of rapidly and extensively degrading linear paraffins from n-C10 to n-C24 of two different commercial largely used diesel fuels under well defined 
Table 3 Phylogenetic identification of isolates obtained from ENZ-G1 and ENZ-G2 consortia

\begin{tabular}{|c|c|c|c|}
\hline Consortium & Isolate & Closest Relative [GenBank Accession number] & Identity \\
\hline ENZ-G1 \& ENZ-G2 & ENZ1 & Acinetobacter baumannii DSM 30007 (T) [X81660] & $100 \%$ \\
\hline ENZ-G1 \& ENZ-G2 & ENZ2 & Chryseobacterium taichungense strain CC-TWGS1-8 [AJ843132] & $98 \%$ \\
\hline ENZ-G1 \& ENZ-G2 & ENZ3 & Alcaligenes sp. NyZ215 [EF540877] & $100 \%$ \\
\hline ENZ-G1 \& ENZ-G2 & ENZ4 & Pseudomonas stutzeri strain SA1 [DQ059546] & $99 \%$ \\
\hline ENZ-G1 \& ENZ-G2 & ENZ6 & Stenotrophomonas acidiminiphila strain D3 [EU301768] & $99 \%$ \\
\hline ENZ-G2 & ENZ7 & Gordonia amicalis Type strain IEGM [AF101418] & $100 \%$ \\
\hline ENZ-G1 \& ENZ-G2 & ENZ8 & Trametes gibbosa strain 911030 [EU1620578] & $100 \%$ \\
\hline
\end{tabular}

laboratory conditions and this thanks to their richness of quite diverse microbes, such as bacteria and the fungus Trametes gibbosa. Their remarkable and reproducible biodegradation potential together with their resistance to chryopreservation make ENZ-G1 and ENZ-G2 consortia very interesting candidates for bioaugmentation operations on diesel fuels impacted sites. Given their very similar composition and biodegradation activity both these mixed cultures are equally promising in the bioaugmentation practice of soils contaminated by diesel fuels. Laboratory scale studies addressed to test both cultures on actual site soils are currently in progress. However, the main lesson learnt in this study is that fungi can be enriched together with bacteria through the enrichment procedures conventionally adopted for obtaining consortia of highly specialized aerobic bacteria. Thus, the occurrence of fungi in mixed bacterial cultures previously obtained with the same procedure cannot be excluded.

\section{Methods}

\section{Source of microorganisms and chemicals}

ENZYVEBA, which is a partially characterized stable consortium of aerobic and anaerobic bacteria and fungi [25-28], was employed as the source of diesel fuel hydrocarbon-degrading microorganisms. It was obtained 

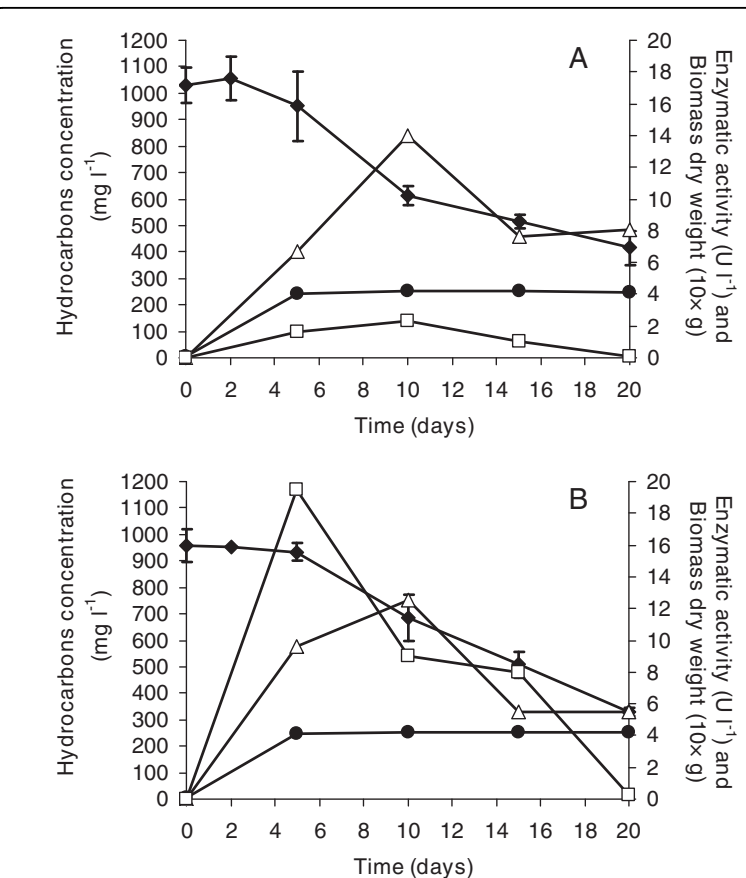

Figure 5 Growth of the fungal isolate Trametes gibbosa on diesel fuels. Growth of the fungal isolate Trametes gibbosa on MMM medium amended with G1 (A) and G2 (B) diesel fuels as the sole carbon and energy source. Black diamond: Hydrocarbons concentration; Black circle: dry weight biomass; White triangle: Laccase activity; White square: Mn-dependent peroxidase activity.

by MARCOPOLO ENGINEERING S.p.A. (Italy) from selected organic matter through a twenty-years culture enrichment process (MPE Mesen Patented - No. 01286120) and was partially characterized through conventional and molecular procedures [25,28]. A 30\% w/v suspension of ENZYVEBA in sterile water was incubated at $37^{\circ} \mathrm{C}$ and $100 \mathrm{rpm}$ for $24 \mathrm{hrs}$ and used to inoculate the first enrichment culture.

Solvents and chemical reagents were obtained from Sigma-Aldrich and Carlo Erba (Milan, Italy) whereas the components of media used for growing microorganisms, i.e., mineral minimal medium (MMM), Tryptic Soy Agar (TSA); and Malt Extract Agar (MEA) and glycerol, were purchased from Biolife Italia (Milan, Italy). The piperacillin/tazobactam combination and gentamicin sulfate were purchased at pharmacies. Molecular biology reagents were purchased from Invitrogen (Milan, Italy).

\section{Diesel fuels employed}

Two different types of commercially available diesel fuels taken from a Petroleum gas station, i.e. Diesel and HiQ Diesel, herewith designated as G1 and G2 respectively, were employed as the sole source of carbon and energy for enriching two distinct diesel fuel-degrading microbial populations from ENZYVEBA.
G1 and G2 have very similar distillation temperatures, viscosity and density but differ significantly in the content of sulfur and additives with detergent, antifoaming and anticorrosion properties as well as in cetane number. In particular, G2 has, with respect to G1, a lower sulfur content $\left(10 \mathrm{mg} \mathrm{kg}^{-1}\right.$ versus $\left.50 \mathrm{mg} \mathrm{kg}^{-1}\right)$, a higher cetane number (53 versus 51), and a content of additives with lubricant properties (data not shown).

\section{Enrichment and isolation of diesel fuel-degrading cultures from ENZYVEBA}

Two parallel consortia of aerobic microbes able to grow on G1 or G2 diesel hydrocarbons were enriched from ENZYVEBA by using $1.0 \mathrm{l}$ baffled Erlenmeyer flasks equipped with Teflon-coated screw caps containing 0.31 of minimal mineral medium (MMM) amended with 20 $\mathrm{mg} \mathrm{l}^{-1}$ yeast extract (as a source of vitamins) and $1 \mathrm{~g} \mathrm{l}^{-1}$ G1 (or G2) as the main energy and carbon source. In a first phase, 2 identical flasks, one with G1 and the other with $\mathrm{G} 2$, were inoculated at $2 \%(\mathrm{v} / \mathrm{v})$ with the water suspension of ENZYVEBA prepared as mentioned above and incubated at $30^{\circ} \mathrm{C}$ and $150 \mathrm{rpm}$ for 10 days. The flasks were opened daily for 30 minutes to provide $\mathrm{O}_{2}$ by reducing hydrocarbons losses due to volatilization. At the end of the 10-days incubation, each culture was transferred at $2 \% \mathrm{v} / \mathrm{v}$ in a sterile flask containing, as before, $0.3 \mathrm{l}$ of MMM with $20 \mathrm{mg} \mathrm{l}^{-1}$ yeast extract and 1 $\mathrm{g}^{-1} \mathrm{G} 1$ (or G2) and incubated for 10 days under the same conditions. Three other identical sequential transfers were performed of each of the two cultures, thus obtaining, after 5 culture enrichment cycles, two microbial consortia capable of growing on G1 and G2 diesel fuels, designated as ENZ-G1 and ENZ-G2, respectively. To characterize the main microbial features of the two consortia and assay their biodegradation potential, ENZG1 and ENZ-G2 were inoculated in duplicate into sterile MMM with their own diesel fuel and managed as follows. Seventeen $0.1 \mathrm{l}$ baffled Erlenmeyer flasks, containing $20.0 \mathrm{ml}$ of MMM medium amended with 20 $\mathrm{mg} \mathrm{l}^{-1}$ yeast extract and $1 \mathrm{~g} \mathrm{l}^{-1} \mathrm{G} 1$ or G2 were inoculated with ENZ-G1 or ENZ-G2, respectively, and incubated at $30^{\circ} \mathrm{C}$ and $150 \mathrm{rpm}$ for 10 days. On days $0,1,2$, $3,4,6,8$ and 10, two flasks per each enriched culture were subjected to sampling $(1.0 \mathrm{ml}$ aliquot) for the analysis of total viable biomass concentration, and the remaining culture broth was extracted for qualitative and quantitative analysis of diesel fuel hydrocarbons. On day 10, an additional flask of each grown mixed culture was used for community DNA extraction and to prepare culture stocks in glycerol (20\% v/v in MMM medium) that were frozen in liquid nitrogen and chryopreserved at $-20^{\circ} \mathrm{C}$. Sixteen controls were also set up according to the same procedure for ENZ-G1 and ENZ-G2, sterilized after inoculation and used to measure possible abiotic 
losses of hydrocarbons all along the experiment. After a six-month period of storage at $-20^{\circ} \mathrm{C}, \mathrm{ENZ}-\mathrm{G} 1$ and ENZ-G2 were re-inoculated in MMM amended with 20 $\mathrm{mg} \mathrm{l}^{-1}$ yeast extract and $1 \mathrm{~g} \mathrm{l}^{-1}$ of their own diesel fuel and further sub-cultured for additional 3 cycles, as described above, in order to remove glycerol traces from the culture, and analyzed for hydrocarbon biodegradation and microbial community composition.

Bacterial isolates capable of growing on G1 and G2 were obtained from ENZ-G1 and ENZ-G2, respectively, by growing the two cultures on TSA agar plates, toothpicking single colonies having different morphology and transferring them into liquid MMM supplemented with $20 \mathrm{mg} \mathrm{l}^{-1}$ yeast extract and $1.0 \mathrm{~g} \mathrm{l}^{-1} \mathrm{G} 1$ or G2 as the sole carbon and energy source. Each isolate was sub-cultured at least two times in the same medium under the same conditions. Purity of isolates was verified by streaking their liquid cultures on TSA plates. Isolates were grouped into ARDRA (Amplified Ribosomal DNA Restriction Analysis) Operational Taxonomic Units (OTUs) and phylogenetically identified as described below.

Fungi were also obtained from MEA agar plates supplemented with antibiotics (gentamicine $40 \mathrm{mg} \mathrm{l}^{-1}$ and piperacilline plus tazobactam $100 \mathrm{mg} \mathrm{l}^{-1}$ ) and inoculated with ENZ-G1 and ENZ-G2, respectively. The fungal isolates were characterized via genetic analysis as reported below.

The ability of the bacterial isolates to grow on and biodegrade the diesel fuel used for their selection was studied by inoculating a cell suspension of each of them prepared in MMM in duplicate MMM cultures with 20 $\mathrm{mg} \mathrm{l}^{-1}$ yeast extract and $1 \mathrm{~g} \mathrm{l}^{-1} \mathrm{G1}$ (or G2) incubated at $30^{\circ} \mathrm{C}$ and $150 \mathrm{rpm}$ for 10 days according to the approach adopted for quantifying the activity of ENZG1 and ENZ-G2 described above. To determine the diesel fuel biodegradation capability of fungal isolates, the same approach was used with the following modifications. Twenty-two 0.11 baffled Erlenmeyer flasks, containing $20.0 \mathrm{ml}$ of MMM medium amended with $20 \mathrm{mg}$ $\mathrm{l}^{-1}$ yeast extract and $1 \mathrm{~g} \mathrm{l}^{-1} \mathrm{G} 1$ or G2, were inoculated with a cell suspension of the fungal isolate prepared in MMM and incubated at $30^{\circ} \mathrm{C}$ and $150 \mathrm{rpm}$ for 20 days. On days $0,2,5,10,15$ and 20, two flasks were used to extract and analyse qualitatively and quantitatively diesel fuel hydrocarbons. On days 0, 5, 10, 15 and 20, two additional flasks were subjected to sampling of a $0.5 \mathrm{ml}$ aliquot for the analysis of ligninolitic enzyme activities and the remaining culture broth was used for fungal biomass dry weight determination. Killed controls were also set up and sacrificed on days 0 and 20 to measure possible abiotic losses of hydrocarbons.

\section{Analytical procedures}

G1 and G2 hydrocarbons were batch extracted from MMM liquid cultures of both enriched and pure cultures with 1 volume of a mixture of hexane:acetone (9:1) and sonication for $10 \mathrm{~min}$. The qualitative and quantitative analysis of G1 and G2 hydrocarbons occurring in the organic extracts were performed with a gas chromatograph (5890 series II), equipped with a HP-5 capillary column ( $30 \mathrm{~m}$ by $0.25 \mathrm{~mm}$ ) and a flame ionization detector (FID) (Hewlett-Packard Co., Palo Alto, CA, USA). All runs were conducted under the following conditions: initial temperature, $60^{\circ} \mathrm{C}$; isothermal for 1

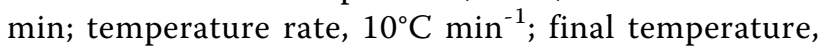
$320^{\circ} \mathrm{C}$; isothermal for $5 \mathrm{~min}$. The injector (splitless mode) was at $270^{\circ} \mathrm{C}$, FID at $320^{\circ} \mathrm{C}$; carrier gas $\left(\mathrm{N}_{2}\right)$ flow rate was $60 \mathrm{ml} \mathrm{min}^{-1}$ and the injected sample volume of $1 \mu \mathrm{l}$. GC peaks were characterized by injecting standards of target $n$-paraffins under the same conditions. Quantitative analysis of G1 and G2 linear hydrocarbons as well as of the overall G1 and G2 hydrocarbons was performed by running five-points linear calibrations of target $n$-paraffins (UltraScientific, N. Kingstown, RI, USA) and of both diesel fuels in the concentration range of 50-1000 $\mathrm{mg} \mathrm{l}^{-1}$ under the same analytical conditions. The biodegradation of G1 and G2 hydrocarbons was determined by performing duplicate analyses of the organic extracts obtained from each culture sacrificed at each sampling time and subtracting the abiotic losses quantified in the parallel sterile controls.

The concentration of the total aerobic cultivable bacteria was determined through the colony counting technique on TSA plates. It was expressed as the mean of colony forming units per ml counted on duplicate samples collected from the two duplicate flasks at each sampling time.

The fungal growth was evaluated as dried weight at each sampling time when the biomasses were filtered on filter paper (Whatman type 1), placed in an oven and dried at a temperature of $65^{\circ} \mathrm{C}$ for $24 \mathrm{~h}$; then they were weighed and the dry weight of the fungal biomass was calculated.

Laccase activity was assayed at $25^{\circ} \mathrm{C}$ using $2.2^{\prime}$-azinobis (3-ethylbenzothiazoline-6-sulfonic acid) (ABTS) as substrate [50]. Mn-peroxidase and $\mathrm{Mn}$-independent peroxidase activities were measured at $25^{\circ} \mathrm{C}$ using DMAB/MBTH [3-dimethylaminobenzoic acid/3-methyl2-benzothiazolinone hydrazone hydrochloride] as substrates [51]. Lignino-peroxidase activity was assayed at $35^{\circ} \mathrm{C}$ using veratryl alcohol as substrate [52]. All the enzyme activities were expressed in International Units (IU), where 1 unit is defined as the amount of enzyme that oxidize $1 \mu$ mole of substrate in 1 minute. 
Genomic DNA extraction from mixed and pure cultures and bacterial and fungal gene amplification

Genomic DNA was extracted from the pellets resulting from centrifugation of $2.0 \mathrm{ml}$ active mixed and pure bacterial cultures using a procedure modified from Kerkhof and Ward [53]. Cell pellets were suspended in 0.3 $\mathrm{ml}$ of a buffer solution containing $25 \mathrm{mM}$ TRIS pH 8.0, $10 \mathrm{mM}$ EDTA and $50 \mathrm{mM}$ glucose. DNA extraction consisted of 8 freeze and thaw cycles in liquid nitrogen/ water bath $\left(37^{\circ} \mathrm{C}\right)$ followed by addition of $0.1 \mathrm{ml}$ of the same buffer solution containing $5 \mathrm{mg} \mathrm{ml}^{-1}$ of lysozyme and of $50 \mu \mathrm{l}$ of $0.5 \mathrm{M}$ EDTA, and by incubation on a rotary shaker at $37^{\circ} \mathrm{C}$ for $30 \mathrm{~min}$. Fifty $\mu \mathrm{l}$ of $10 \%(\mathrm{w} / \mathrm{v})$ SDS were then added and samples were immediately extracted twice with TRIS ( $\mathrm{pH}$ 8.0) saturated phenol: chlorophorm:isoamylalcol $(25: 24: 1)$. The mixture was vortexed vigorously to form an emulsion and centrifuged at $12500 \times \mathrm{g}$ for $3 \mathrm{~min}$ before removing the nonaqueous phase. DNA was then precipitated with 0.1 volumes sodium acetate $3 \mathrm{M} \mathrm{pH} 5.2$ and 2 volumes $100 \%$ cold ethanol, pelleted at $12500 \times \mathrm{g}$ for $20 \mathrm{~min}$ and washed twice with $0.25 \mathrm{ml} 70 \%$ cold ethanol at $12500 \times$ $\mathrm{g}$ for $10 \mathrm{~min}$. DNA pellets were air dried and resuspended in $50 \mu$ l deionized water. 16S rRNA gene PCR amplification was performed with a T-gradient Thermocycler (Biometra, Göttingen, Germany). Amplification reaction mixtures contained $1 \times$ PCR buffer, $1.5 \mathrm{mM}$ $\mathrm{MgCl}_{2}$, a $0.2 \mathrm{mM}$ concentration of each dNTP, a 0.4 $\mathrm{mM}$ concentration of each primer, $2.0 \mathrm{U}$ of Taq polymerase, and $2.0 \mu \mathrm{l}$ of template DNA in a final volume of $50 \mu \mathrm{l}$. The primers pairs used were $27 \mathrm{f}$ (5'-AGA GTT TGA TCC TGG CTC AG-3') - 1495r (5'-GTT TAC CTT GTT ACG ACT T-3') [54] and GC-357f, containing a 40 bp GC-clamp, (5'-CGC CCG CCG CGC CCC GCG CCC GGC CCG CCG CCC CCG CCC CCC TAC GGG AGG CAG CAG-3') - 907r (5'-CCG TCA ATT CCT TTG AGT TT-3') [55], depending on the following processing of the PCR-amplified product. Reaction mixtures were held at $94^{\circ} \mathrm{C}$ for $2 \mathrm{~min}$, followed by 30 cycles of amplification at $94^{\circ} \mathrm{C}$ for $30 \mathrm{~s}, 55^{\circ} \mathrm{C}$ for 30 $\mathrm{s}$, and $72^{\circ} \mathrm{C}$ for $45 \mathrm{~s}$ and a final extension of $72^{\circ} \mathrm{C}$ for 10 min. Amplification products were analyzed in $1.0 \%(\mathrm{w} /$ v) agarose gel stained with ethidium bromide.

Genomic DNA of fungal isolates was extracted using the DNeasy plant mini kit (Qiagen, Germany) according to the manufacturer's instructions. The ITS region of the nuclear ribosomal DNA (5.8S) was amplified using the forward primer ITS1F (5' CTTGGTCATTTAGAGGAAGTAA 3') [56] and the reverse primer ITS4 (5' TCCTCCGCTTATTGATATGC 3') [57]. The PCR reactions were performed in $50 \mu \mathrm{l}$ volume. The DNA concentration was $30 \mathrm{ng} \mathrm{ml}^{-1}$. PCR took place under the following conditions: $95^{\circ} \mathrm{C}$ for $5 \mathrm{~min}$; $94^{\circ} \mathrm{C}$ for $45 \mathrm{sec}$, $56^{\circ} \mathrm{C}$ for $45 \mathrm{sec}, 72^{\circ} \mathrm{C}$ for $45 \mathrm{sec}$ (35 cycles); $72^{\circ} \mathrm{C}$ for 7 min. The reaction was then maintained at $4^{\circ} \mathrm{C}$. The resulting amplification products were analyzed by $1 \%$ $(\mathrm{w} / \mathrm{v})$ agarose gel electrophoresis.

\section{S rRNA genes clonal libraries}

PCR-amplified 16S rRNA genes obtained from genomic DNA of mixed cultures with the primer pair 27F-1495r were cloned in $\mathrm{pCR}^{\circ} 4-\mathrm{TOPO}^{\circ}$ cloning vector (Invitrogen, Paisley, UK) and the resulting plasmids were inserted in chemically competent One Shot ${ }^{\circledR}$ TOP10 E. coli cells (Invitrogen, Paisley, UK) according to the manufacturer's instructions. Transformed cells were plated on LB agar plates containing $100 \mu \mathrm{g} \mathrm{ml}^{-1}$ ampicillin and incubated overnight at $37^{\circ} \mathrm{C}$. Fifty colonies from each clonal library were tooth-picked and grown overnight in liquid LB medium with $100 \mu \mathrm{g} \mathrm{ml}^{-1}$ ampicillin. Library screening used plasmid extraction, PCR amplification of insert and digestion with the restriction enzyme AluI to identify unique banding patterns. Plasmids extractions used a modified alkaline lysis miniprep protocol [58]. PCR amplification of inserts was performed with primer pair $27 \mathrm{f}-1495 \mathrm{r}$ as described above in a final volume of $25 \mu$ l. Restriction reaction mixtures contained $1 \times$ REact $^{\oplus} 1$ buffer (Invitrogen, Paisley, UK), approximately $0.5 \mu \mathrm{g}$ of DNA and $2 \mathrm{U}$ of AluI in a final volume of 20 $\mu \mathrm{l}$. Restriction digestion was performed at $37^{\circ} \mathrm{C}$ for $6 \mathrm{hrs}$ followed by enzyme inactivation at $65^{\circ} \mathrm{C}$ for $10 \mathrm{~min}$. The restriction digests were separated in $2 \%(\mathrm{w} / \mathrm{v})$ agarose gels in $0.5 \times$ TBE buffer. Amplified inserts bearing a unique restriction banding pattern were sequenced with primer $27 \mathrm{f}$ as described below.

\section{DGGE analysis}

PCR-amplified 16S rRNA genes obtained from genomic DNA of mixed cultures with the primer pair GC357f $907 \mathrm{r}$ were separated on the basis of their melting behaviour by denaturing gradient gel electrophoresis (DGGE). DGGE fingerprint was performed with a DCode apparatus (Bio-Rad, Milan, Italy) in a $7 \%(\mathrm{w} / \mathrm{v})$ polyacrylamide gel (acrylamide-N, N'-methylenebisacrylamide, 37:1) in $1 \times$ TAE with a denaturing gradient of $40 \%$ (top) to $55 \%$ (bottom) denaturant, where $100 \%$ denaturant is $7 \mathrm{M}$ urea and $40 \%(\mathrm{v} / \mathrm{v})$ formamide. The electrophoresis was run at $55 \mathrm{~V}$ for $16 \mathrm{hrs}$ at $60^{\circ} \mathrm{C}$. The gel was stained in a solution of $1 \times$ SYBR-Green in $1 \times$ TAE for $30 \mathrm{~min}$ and its image captured in UV transillumination with a digital camera supported by a Gel Doc apparatus (Bio-Rad, Milan, Italy). Bands were cut from the gel with a sterile scalpel and DNA was eluted by incubating the gel fragments for $16 \mathrm{hrs}$ in $50 \mu \mathrm{l}$ of sterile deionized water at $4^{\circ} \mathrm{C}$. Two $\mu$ l of the solution were then used as template to re-amplify the band fragment using the same primers without the GC-clamp (357f$907 r$ ) and the same PCR conditions described above. 
The obtained amplicons were then sequenced with primer $357 \mathrm{f}$ as described below.

\section{ARDRA}

16S rRNA genes of pure cultures amplified with the primer pair $27 \mathrm{f}$ - $1495 \mathrm{r}$ were digested with the restriction enzyme AluI to identify unique restriction patterns as described for the clonal library screening. The restriction digests were separated in $2 \%(\mathrm{w} / \mathrm{v})$ agarose gels in $0.5 \times \mathrm{TBE}$ buffer and isolates were grouped into Operational Taxonomic Units (OTUs) having unique restriction patterns. The PCR-amplified 16S rRNA gene of one representative of each OTU was sequenced with primer $27 \mathrm{f}$ as described below.

\section{Sequencing and phylogenetic analysis}

Sequencing of bacterial 16S rRNA amplicons was performed after purification with EXOSAP (USB Corporation, Cleveland, Ohio, US) according to the manufacturer's instructions. Sequencing reactions and runs were performed by BMR Genomics (Padova, Italy).

For each $16 \mathrm{~S}$ rDNA sequence, the most closely related sequence and the sequence of the most closely related cultured bacterial strain were retrieved from the GenBank database by using MEGABLAST and from the Ribosomal Database Project-II by using the SEQUENCE $\mathrm{MATCH}$ tool. The sequences were aligned with the CLUSTAL W program and phylogenetic trees were calculated with the neighbour-joining method. Bootstrap values were determined from 1000 iterations. The fungal ITS region was sequenced in both strands using the primers ITS1F and ITS4. Sequences were obtained with a rapid (24 h) automated capillary electrophoresis system CEQ 2000 (Beckman Coulter, USA). The ITS sequences were compared to the GenBank (NCBI) database by BlastN algorithm BLASTN 2.2.18+ (September-26-2008) to identify the isolate or reveal the closest known analogue.

\section{Acknowledgements}

This study was financed by the University of Bologna and by MARCOPOLO ENGINEERING Spa (Cuneo, Italy), which also supplied the source of microorganisms ENZYVEBA.

\section{Author details \\ 'DICASM, Faculty of Engineering, University of Bologna, via Terracini 28, 40131 Bologna, Italy. ${ }^{2}$ MARCOPOLO ENGINEERING Spa, via XI Settembre 37, 12011 Borgo San Dalmazzo (CN), Italy. ㄹepartment of Plant Biology, University of Torino, Viale Mattioli 25, 10125 Torino, Italy.}

\section{Authors' contributions}

GZ participated in the design of the study, performed the molecular analysis of microbial communities and drafted the manuscript. SDT participated in the design of the study and performed the enrichment and isolation of bacterial cultures. DT performed the hydrocarbons biodegradation experiments. GCV carried out the isolation and characterization of the fungal isolate and participated in the manuscript preparation. AB commented on the manuscript. FF coordinated the research as well as the manuscript preparation. All the authors read and approved the final manuscript.

\section{Competing interests}

SDT, DT and $A B$ received their salary from MARCOPOLO ENGINEERING Spa, which also provided ENZYVEBA and partially financed the research. The other authors declare that they have no competing interests.

Received: 12 November 2009

Accepted: 16 February 2010 Published: 16 February 2010

\section{References}

1. Wang $X$, Bartha R: Effects of bioremediation on residues, activity and toxicity in soil contaminated by fuel spills. Soil Biol Biochem 1990, 22:501-505.

2. Leahy JG, Colwell RR: Microbial degradation of hydrocarbons in the environment. Microbiol Rev 1990, 54:305-315.

3. Huesemann $\mathrm{MH}$ : Predictive model for estimating the extent of petroleum hydrocarbon biodegradation in contaminated soils. Environ Sci Technol 1995, 29:7-18.

4. van Hamme JD, Singh A, Ward OP: Recent advances in petroleum microbiology. Microbiol Mol Biol Rev 2003, 67:503-549.

5. Rambeloarisoa E, Rontani JF, Giusti G, Duvnjak Z, Bertrand JC: Degradation of crude oil by a mixed population of bacteria isolated from sea-surface foams. Mar Biol 1984, 83:69-81.

6. Richard JY, Vogel TM: Characterization of a soil bacterial consortium capable of degrading diesel fuel. Int Biodeterior Biodegradation 1999, 44:93-100.

7. Alexander M: Biodegradation and Bioremediation San Diego (CA, USA): Academic Press California, 21999

8. Casellas M, Grifoli M, Sabaté J, Solanas AM: Isolation and characterization of a 9-fluorenoned-degrading bacterial strain and its role in synergistc degradation of fluorene by a consortium. Can J Microbiol 1998, 44:734-742.

9. Ghazali FM, Rahaman RNZA, Salleh AB, Basri M: Biodegradation of hydrocarbons in soil by microbial consortium. Int Biodeterior Biodegradation 2004, 54:61-67.

10. Anastasi A, Varese GC, Bosco F, Chimirri F, Marchisio VF: Bioremediation potential of basidiomycetes isolated from compost. Bioresour Technol 2008, 99:6626-30.

11. Anastasi A, Coppola T, Prigione V, Varese GC: Pyrene degradation and detoxification in soil by a consortium of basidiomycetes isolated from compost: role of laccases and peroxidases. J Hazard Mater 2009, 165:1229-33.

12. Gallego JLR, Loredo J, Llamas JF, Vázquez F, Sánchez J: Bioremediation of diesel-contaminated soils: Evaluation of potential in situ techniques by study of bacterial degradation. Biodegradation 2001, 12:325-335.

13. Spinelli LF, Schnaid F, Selbach PA, Bento FM, Oliveira JR: Enhancing bioremediation of diesel oil and gasoline is soil amended with a agroindustry sludge. J Air Waste Manage Assoc 2005, 55:421-429.

14. Di Toro S, Mascalzi G, Brondello L, Perosino M, Fava F: Determinazione e caratterizzazione dell'effetto dell'inoculo Enzyveba nella bioremediation aerobica di suoli storicamente contaminati da idrocarburi policiclici aromatici. Tecnologie innovative per l'industrializzazione del sistema ambiente: acqua, siti contaminati, atmosfera, politiche energetiche, certificazioni ambientali, organismi geneticamente modificati Milano (Italy): MaggioliMorselli L 2005, 420-426.

15. Di Toro S, Zanaroli G, Fava F: Intensification of the aerobic bioremediation of an actual site soil historically contaminated by polychlorinated biphenyls (PCBs) through bioaugmentation with a non acclimated, complex source of microorganisms. Microb Cell Fact 2006, 5:11.

16. Di Toro S, Zanaroli G, Varese GC, Filipello Marchisio V, Fava F: Role of Enzyveba in the aerobic bioremediation and detoxification of a soil freshly contaminated by two different diesel fuels. Int Biodeterior Biodegradation 2008, 62:153-161.

17. Hamdi H, Manusadžanas L, Aoyama I, Jedidi N: Effects of anthracene, pyrene and benzo[a]pyrene spiking and sewage sludge compost amendment on soil ecotoxicity during a bioremediation process. Chemosphere 2006, 65:1153-1162.

18. Hamdi H, Benzarti S, Manusadzianasc L, Aoyamaa I, Jedidid N: Bioaugmentation and biostimulation effects on $\mathrm{PAH}$ dissipation and soil 
ecotoxicity under controlled conditions. Soil Biol Biochem 2007, 39:1926-1935.

19. Venkata Mohan S, Prasanna D, Purushotham Reddy B, Sarma PN: Ex situ bioremediation of pyrene contaminated soil in bio-slurry phase reactor operated in periodic discontinuous batch mode: Influence of bioaugmentation. Int Biodeterior Biodegradation 2008, 62:162-169.

20. Sahlström L, Aspan A, Bagge E, Danielsson-Tham L-M, Albihn A: Bacterial pathogen incidences in sludge from Swedish sewage treatment plants. Water Res 2004, 38:1989-1994.

21. Wéry N, Lhoutellier C, Ducray F, Delgenès J-P, Godon J-J: Behaviour of pathogenic and indicator bacteria during urban wastewater treatment and sludge composting, as revealed by quantitative PCR. Water Res 2008, 42:53-62.

22. Viñas M, Grifoli M, Sabaté J, Solanas AM: Biodegradation of a crude oil by three microbial consortia of different origins and metabolic capabilities. J Ind Microbiol Biotechnol 2002, 28:252-260.

23. Ambujom S: Studies on composition and stability of a large membered bacterial consortium degrading phenol. Microbiol Res 2001, 156:293-301.

24. Coats ER, Loge FJ, Smith WA, Thompson DN, Wolcott MP: Functional stability of a mixed microbial consortium producing PHA from waste carbon sources. Appl Biochem Biotechnol 2007, 136-140:909-925.

25. Anastasi A, Varese GC, Voyron S, Scannerini S, Filipello Marchisio V: Characterization of fungal biodiversity in compost and vermicompost. Compost Sci Util 2004, 12:185-191.

26. Anastasi A, Varese GC, Filipello Marchisio V: Isolation and identification of fungal communities in compost and vermicompost. Mycologia 2005, 97:33-44.

27. Pietronave S, Fracchia L, Rinaldi M, Martinotti MG: Influence of biotic and abiotic factors on human pathogens in a finished compost. Water Res 2004, 38:1963-1970.

28. Fracchia $L$, Dohrmann AB, Martinotti MG, Tebbe CC: Bacterial diversity in a finished compost and vermicompost: differences revealed by cultivation-independent analyses of PCR-amplified 16S rRNA genes. Appl Microbiol Biotechnol 2006, 71:942-952.

29. Diaz-Ramirez IJ, Escalante-Espinosa E, Favela-Torres E, Gutierrez-Rojas M, Ramirez-Saad H: Design of bacterial defined mixed cultures for biodegradation of specific crude oil fractions, using population dynamics analysis by DGGE. Int Biodeterior Biodegradation 2008, 62:21-30.

30. Riis V, Kleinsteuber S, Babel W: Influence of high salinities on the degradation of diesel fuel by bacterial consortia. Can J Microbiol 2003, 49:713-21

31. Lee M, Kim MK, Singleton I, Goodfellow M, Lee ST: Enhanced biodegradation of diesel oil by a newly identified Rhodococcus baikonurensis EN3 in the presence of mycolic acid. J Appl Microbiol 2006, 100:325-33.

32. Zhukov DV, Murygina VP, Kalyuzhnyi SV: Kinetics of the degradation of aliphatic hydrocarbons by the bacteria Rhodococcus ruber and Rhodococcus erythropolis. Appl Biochem Microbiol 2007, 43:587-592.

33. Kragelund C, Kong Y, Waarde van der J, Thelen K, Eikelboom D, Tandoi V, Thomsen TR, Nielsen PH: Ecophysiology of different filamentous Alphaproteobacteria in industrial wastewaters treatment plants. Microbiology 2006, 152:3003-3012.

34. Kauffmann IM, Schmitt J, Schmid RD: DNA isolation from soil samples for cloning in different hosts. Appl Microbiol Biotechnol 2004, 64:665-670.

35. van Hamme JD, Odumeru JA, Ward OP: Community dynamics of a mixedbacterial culture growing on petroleum hydrocarbons in batch culture. Can J Microbiol 2000, 46:441-50

36. Mishra S, Jyot J, Kuhad RC, Lal B: Evaluation of inoculum addition to stimulate in situ bioremediation of oily-sludge-contaminated soil. Appl Environ Microbiol 2001, 67:1675-1681.

37. Pepi M, Minacci A, Di Cello F, Baldi F, Fani R: Long-term analysis of diesel fuel consumption in a co-culture of Acinetobacter venetianus, Pseudomonas putida and Alcaligenes faecalis. Antonie Van Leeuwenhoek 2003, 83:3-9.

38. Ueno A, Hasanuzzaman M, Yumoto I, Okuyama H: Verification of degradation of $n$-alkanes in diesel oil by Pseudomonas aeruginosa strain WatG in soil microcosms. Curr Microbiol 2006, 52:182-185.

39. Das K, Mukherjee AK: Crude petroleum-oil biodegradation efficiency of Bacillus subtilis and Pseudomonas aeruginosa strains isolated from a petroleum-oil contaminated soil from north-east India. Bioresour Technol 2007, 98:1339-1345.
40. Quatrini P, Scaglione G, De Pasquale C, Riela S, Puglia AM: Isolation of Gram-positive n-alkane degraders from a hydrocarbon-contaminated Mediterranean shoreline. J Appl Microbiol 2008, 104:251-259.

41. Li Y-Q, Liu H-F, Tian Z-L, Zhu L-H, Wu Y-H, Tang H-Q: Diesel pollution biodegradation: synergetic effect of Mycobacterium and filamentous fungi. Biomed Environ Sci 2008, 21:181-187.

42. Venkateswaran K, Harayama S: Sequential enrichment of microbial populations exhibiting enhanced biodegradation of crude oil. Can J Microbiol 1995, 41:767-75.

43. Cavalca L, Confalonieri A, Larcher S, Andreoni V: Evolution of a degradative bacterial consortium during the enrichment of naphtha solvent. J Appl Microbiol 2000, 88:1009-1018.

44. Jacques RJS, Okeke BC, Bento FM, Peralba MCR, Camargo FAO: Improved Enrichment and Isolation of Polycyclic Aromatic Hydrocarbons (PAH)Degrading Microorganisms in Soil Using Anthracene as a Model PAH. Curr Microbiol 2009, 58:628-634.

45. Owsianiak M, Szulc A, Chrzanowski L, Cyplik P, Bogacki M, OlejnikSchmidt AK, Heipieper HJ: Biodegradation and surfactant-mediated biodegradation of diesel fuel by 218 microbial consortia are not correlated to cell surface hydrophobicity. Appl Microbiol Biotechnol 2009, 84:545-553.

46. Haritash AK, Kaushik CP: Biodegradation aspects of polycyclic aaromatic hydrocarbons (PAHs): a review. J Hazard Mater 2009, 169:1-15.

47. Nyanhongo GS, Gübitz G, Sukyai P, Leitner C, Haltrich D, Ludwig R: Oxidoreductases from Trametes spp. in biotechnology: a wealth of catalytic activity. Food Technol Biotechnol 2007, 45:250-268.

48. Lucas M, Mertens V, Corbisier A-M, Vanhulle S: Synthetic dyes decolourisation by white-rot fungi: development of original microtitre plate method and screening. Enzyme Microb Technol 2008, 42:97-106.

49. Sutherland JB: Degradation of hydrocarbons by yeast and filamentous fungi. Fungal biotechnology in agricultural, food and environmental applications Marcel Dekker, Inc.Arora DK

50. Niku-Paavola ML, Karhunen E, Salola P, Raunio V: Ligninolytic enzymes of the white-rot fungus Phlebia radiate. Biochem J 1998, 254:877-884.

51. Vyas BRM, Volc J, Sasek V: Effects of temperature on the production of manganese peroxidase and lignin peroxidase by Phanerochaete chrysosporium. Folia Microbiol 1994, 39:19-22.

52. Tien M, Kirk TK: Lignin-degrading enzyme from the Hymenomycete Phanerochaete chrysosporium Burds. Science 1983, 221:661-663.

53. Kerkhof L, Ward BB: Comparison of Nucleic Acid Hybridization and Fluorometry for Measurement of the Relationship between RNA/DNA Ratio and Growth Rate in a Marine Bacterium. Appl Environ Microbiol 1993, 59:1303-1309.

54. Weisburg WG, Barns SM, Pelletier DA, Lane DJ: 16 S ribosomal DNA amplification for phylogenetic study. J Bacteriol 1991, 173:697-703.

55. Sass AM, Sass H, Coolen MJ, Cypionka H, Overmann J: Microbial communities in the chemocline of a hypersaline deep-sea basin (Urania basin, Mediterranean Sea). Appl Environ Microbiol 2001, 67:5392-5402.

56. Gardes M, Bruns TD: ITS primers with enhanced specificity for basidiomycetes-application to the identification of mycorrhizae and rusts. Mol Ecol 1993, 2:113-8.

57. White TJ, Bruns T, Lee S, Taylor J: Amplification and direct sequencing of fungal ribosomal RNA genes for phylogenetics. PCR Protocols: A Guide to Methods and Applications San Diego: Academic PressInnis MA, Gelfand DH, Shinsky JJ, White TJ 1990, 315-322.

58. Sambrook J, Fritsch ER, Maniatis T: Molecular Cloning: A Laboratory Manual Cold Spring Harbor (NY): Cold Spring Harbor Laboratory Press, 21989.

doi:10.1186/1475-2859-9-10

Cite this article as: Zanaroli et al:: Characterization of two diesel fuel degrading microbial consortia enriched from a non acclimated, complex source of microorganisms. Microbial Cell Factories 2010 9:10. 